\title{
SISTEM SAPAAN BAHASA BALI MENURUT HUBUNGAN KEKERABATAN
}

\author{
I Nyoman Suwija \\ Program Studi Pendidikan Bahasa Indonesia dan Daerah \\ Fakultas Pendidikan Bahasa dan Seni, IKIP PGRI Bali \\ E-mail: inyoman.suwija63@gmail.com
}

\begin{abstract}
ABSTRAK. Sebagai bahasa ibu suku Bali, bahasa Bali masih diajarkan sebagai mata pelajaran muatan lokal pada jenjang pendidikan sekolah dasar, sekolah menengah pertama, dan sekolah menengah atas. Mengamati eksistensi bahasa Bali seperti itu, penyusunan artikel ini bertujuan untuk memerikan sistem sapaan bahasa daerah Bali. Untuk mencapai tujuan tersebut, penelitian ini menggunakan teori sosiolinguistik Fishman (1986). Dalam pengumpulan data digunakan metode observasi dan metode wawancara. Data yang terkumpul dianalisis dengan metode distribusional. Penyajian hasil analisis data menggunakan metode formal dan informal, dibantu dengan teknik induktif dan deduktif. Kata sapaan dalam bahasa Bali cukup banyak dan bervariasi. Hal itu disebabkan oleh beberapa bentuk hubungan kekerabatan yang meliputi faktor: (1) usia partisipan, (2) kedudukan dalam keluarga, (3) jenis kelamin, dan (4) hubungan keluarga langsung. Bentuk sapaan bahasa Bali tergantung situasi dan status sosial para partisipan. Artinya, pada keluarga wangsa jaba atau orang kebanyakan berbentuk basa andap atau bahasa tingkatan biasa, sedangkan untuk keluarga triwangsa atau bangsawan menggunakan kata-kata bahasa Bali yang halus atau kruna alus.
\end{abstract}

Kata kunci: kata sapaan bahasa Bali, hubungan kekerabatan, sosiolinguistik

\section{BALI LANGUAGE SYSTEM ACCORDING TO KINSIP RELATIONSHIP}

\begin{abstract}
As the mother language of tribe of Bali, the Balinese language is still taught as a local content subject in elementary, junior and senior high school education. Observing the existence of Balinese language, the preparation of this article aims to describe Balinese language greeting system. To achieve this objective, this study used the sociolinguistic theory of Fishman (1986). In the data collection is used method of observation and interview method. The collected data is analyzed by distribution method. Presentation of data analysis result used formal and informal method, assisted by inductive and deductive technique. The word greeting in Balinese is quite numerous and varied. This is due to several forms of kinship relationships that include the following factors: (1) participative age, (2) family status, (3) sex, and (4) direct family relationships. The form of Balinese language greetings depends on the situation and social status of the partisans. It means that the family wangsa jaba or ordinary people the form basa andap or ordinary language level, while for the family triwangsa or nobility use the words of the Balinese language is smooth or kruna alus.
\end{abstract}

Key words: the word of Balinese greeting, kinsip relationship, sociolinguistic

\section{PENDAHULUAN}

Bahasa Bali merupakan bahasa ibu bagi masyarakat Bali. Sebagai bahasa ibu, bahasa Bali berfungsi sebagai alat komunikasi sehari-hari, pendukung kebudayaan dan lambang identitas masyarakat suk Bali. Ketiga fungsi itu dapat diamati melalui kegiatan-kegiatan anggota masyarakat dalam berkomunikasi antara sesamanya. Fungsi dan peranan bahasa Bali yang cukup besar itu mendorong penulis untuk membahas salah satu aspek kebahasaan, yaitu sistem sapaan menurut hubungan kekerabatan.

Kridalaksana (1982) mengatakan bahwa yang termasuk kata-kata sapaan dalam bahasa Bali dapat berbentuk morfem, kata-kata, dan atau frasa. Bentuk katakata sapaan tersebut digunakan untuk saling merujuk dalam situasi pembicaraan yang berbeda-beda menurut sifat hubungan antara pembicara itu.

Penelitian ini merupakan penggambaran hasil inventarisasi sistem sapaan yang terdapat dalam bahasa Bali. Penggambaran itu dilihat dari sistem sapaan yang berlaku di dalam lingkungan keluarga serta kaitannya dengan status, adat, agama, jenis kelamin, kedudukan, dan sopan santun. Unsur-unsur kajian seperti siapa yang menyapa (si pembicara), siapa yang disapa (mitra bicara), serta topik apa yang dibicarakan dapat melahirkan kata atau frasa yang berbentuk sapaan.

Kajian ini berkaitan dengan satuan gramatikal yang berupa klausa. Sebagai satuan gramatikal, klausa dapat dianalisis berdasarkan (i) fungsi unsur-unsurnya, (ii) kategori unsur-unsurnya, dan (iii) peran unsurunsurnya (Ramlan, 1987: 90). Di samping itu, makna yang terkandung dalam sapaan sangat erat kaitannya dengan norma-norma sosial kebahasaan yang berlaku. Dapat pula dikatakan bahwa variasi-variasi pemakaian bahasa mencerminkan pemakai bahasa atau masyarakat penuturnya.

Penelitian ini bertujuan memerikan sistem sapaan yang berlaku dalam kekerabatan masyarakat suku Bali. Oleh karena itu, penelitian ini menggunakan teori sosiolinguistik yang dikemukakan oleh Fishman (1986). Menurutnya, sosiolinguistik mengkaji tingkah laku yang meliputi latar, topik, dan fangsi interaksi. Dengan kata lain, kajian sosiolinguistik tidak memfokuskan perhatian pada fenomena kebahasaan saja, tetapi juga 
memusatkan perhatian pada soal tingkah laku sikap berbahasa, tingkah laku nyata terhadap bahasa dan pemakai bahasa. Dikemukakan pula bahwa kedudukan partisipan dalam masyarakat akan mewujudkan atribut kebahasaan seperti hubungan suami dan istri, atasan dan bawahan, serta aturan-aturan khusus yang berlaku di masyarakat. Koentjaraningrat (1990) menyatakan bahwa di dalam suatu bahasa terdapat sistem penggunaan katakata yang dikenal dengan istilah kekerabatan. Sistem kekerabatan memiliki sangkut-paut yang erat dengan sistem kekerabatan dalam masyarakat. Dipandang dari sudut cara pemakaian istilah kekerabatan pada umumnya, tiap bahasa mempunyai dua macam sistem yang disebut dengan istilah sapaan (term of address) dan acuan (term of reference). Penggunaan istilah sapaan yang tepat terhadap seseorang dapat terjadi jika diawali dengan pengenalan tentang istilah sebutan apa yang diberikan kepada orang yang disapa (pesapa) itu. Hal ini berarti bahwa istilah menyapa dipakai jika kita meyapa atau memanggil seseorang untuk menjadi mitra bicara atau orang kedua, sedangkan istilah menyebut dipakai jika kita berbicara dengan orang lain dan menyebut-nyebut orang yang tidak terlihat dalam situasi pembicaraan atau sebutan kepada orang ketiga.

Terkait pelajaran bahasa daerah Bali, struktur masyarakat Bali dibedakan atas dua golongan, yaitu masyarakat triwangsa dan wangsa jaba. Triwangsa dipakai menyebut tiga kasta (brahmana, ksatria, dan sudra) yang mendapat penghormatan lewat bahasa dan boleh berbahasa biasa terhadap wangsa jaba. Sementara, wangsa jaba merupakan sebutan orang kebanyakan yang berkewajiban berbahasa Bali alus (menghormat) kepada triwangsa. Dengan demikian kata-kata sapaan bahasa Bali cukup banyak variannya.

\section{METODE}

Dalam penelitian ini digunakan metode kualitatif. Penerapan metode kualitatif sejalan dengan pernyataan Djajasudarma (2006:10) bahwa metode kualitatif merupakan prosedur yang menghasilkan data secara deskriptif, baik tulis maupun lisan yang berkembang atau berada di masyarakat (dalam Sofyan, 2015: 263). Lebih lanjut Sofyan mengatakan bahwa terkait metode ini, data dihasilkan secara deskriptif maksudnya untuk membuat gambaran, lukisan secara sistematis, faktual, dan akurat mengenai data, sifat, serta kaitannya dengan fenomenafenomena.

Metode deskriptif dilengkapi dengan tiga metode dan teknik, yaitu metode dan teknik pengumpulan data, metode dan teknik analisis data, serta metode dan teknik penyajian hasil analisis data (Sudaryanto, 1982).

Metode pengumpulan data yang digunakan adalah metode simak. Hal ini sejalan dengan pendapat Sudaryanto (1993: 133) bahwa dalam metode simak digunakan teknik dasar yang meliputi teknik sadap, libat cakap, simak bebas libat cakap, rekam, dan catat (dalam Sofyan: 2015: 263).

Selanjutnya menurut Firdaus (2011: 226), Analisis data, menggunakan metode padan, adalah metode yang dipakai untuk mengkaji atau menentukan identitas satuan diagonal dengan memakai alat penentu yang berada di luar bahasa, terlepas dari bahasa yang bersangkutan (Firdaus, 2011: 226). Penyajian hasil analisis data menggunakan metode formal dan informal, dibantu dengan teknik induktif dan deduktif.

\section{HASIL DAN PEMBAHASAN}

Bilamana seseorang berbicara kepada orang lain, penggunaan bentuk-bentuk sapaan akan sangat tergantung pada hubungan antara penyapa dengan pesapa serta ditentukan oleh beberapa faktor, yaitu: jenis kelamin, usia, kedudukan, penghargaan, sopan santun, dan azas kekeluargaan. Penggunaan kata-kata sapaan sangat erat kaitannya dengan situasi kemasyarakatan dalam kehidupan budaya.

\section{A. Sapaan Menurut Usia}

Faktor usia cukup berpengaruh di dalam kesopanan bertutur sapa. Tidak sembarang kata-kata boleh diucapkan oleh seorang yang lebih muda usianya kepada lawan bicara yang usianya lebih tua. Begitu pula yang lebih tua terhadap yang usia muda, walaupun yang tua lebih leluasa berbicara menurut adat dan budaya, namun bukan berarti keleluasaan itu tanpa batas-batas kesopanan dalam bertutur sapa. Misalnya, yang pantas disapa adi 'adik' disapa adi, yang pantas disapa beli 'kakak lakilaki' disapa beli, yang pantas disapa panak 'anak' disapa panak, yang pantas disapa bapa 'ayah' disapa bapa, yang pantas disapa mémé ibu' disapa mémé, yang pantas disapa pekak 'kakek' disapa pekak, yang pantas disapa dadong 'nenek' disapa dadong,yang pantas disapa uwa 'paman' disapa $u w a$, yang pantas disapa bibi 'bibi' disapa bibi, dan banyak lagi yang lainnya.

Penggunaan kata cai/nyai 'kamu' tidak boleh digunakan dalam percakapan dengan sanak famili atau orang lain, terutama oleh yang lebih muda usianya terhadap yang lebih tua. Misalnya, Made Budi adalah seorang adik dari Wayan Raka. Untuk menanyakan I Wayan Raka akan ke mana oleh Made Budi, tidak boleh menggunakan kalimat berikut.

(1) Cai lakar luas kija to Yan?

'Kamu akan pergi ke mana Wayan?'

Kalimat pertanyaan tersebut sangat umum dan boleh diucapkan dengan mengganti kata sapaannya, sebagai berikut.

(1a) Bli lakar luas kija to, Bli?

'Kakak akan pergi ke mana, Kak?'

Demikian juga misalnya Made Budi mau menanyakan kakak perempuannya yang bernama Putu 
Lestari. Made Budi tidak boleh menggunakan kalimat berikut.

(1b) Nyai lakar luas kija, Luh?

'Kamu akan pergi ke mana, Luh?'

Kata aké'aku' juga tidak sopan diucapkan oleh orang yang usianya lebih muda kepada yang lebih tua, apalagi di kalangan bangsawan atau Triwangsa. Misalnya, seoarang anak kepada ayahnya. Perhatikan contoh berikut.

(2) Aké lakar luas ka Jakarta, Bapa.

'Aku akan berangkat ke Jakarta, Bapak.'

(3) Aké lakar luas ka Jakarta, Cok.

'Aku akan berangkat ke Jakarta, Cokorda.'

Bagi orang yang lebih tua dan atau bagi kalangan bangsawan (brahmana atau ksatria), penggunaan kata aké'aku' pada kalimat (2) dan (3) kurang sopan, sehingga lumrah digunakan kata iang, tiang 'saya'. Kalimat tersebut dapat diubah menjadi kalimat (2a), (2b), dan (3a) di bawah ini.

(2a) Iang lakar luas ka Jakarta, Bapa.

'Saya akan berangkat ke Jakarta, Bapak.'

(2b) Tiang lakar luas ka Jakarta, Bapa.

'Saya akan berangkat ke Jakarta, Bapak.'

(3a) Titiang jagi luas ka Jakarta, Ratu/Cok/Gusti/ Gung/Dewa.

'Saya akan berangkat ke Jakarta, Ratu/Cok/ Gusti/Gung/Dewa.'

\section{B. Sapaan Menurut Kedudukan dalam Keluarga}

Penyapa dan pesapa harus menyadari kedudukannya di dalam keluarga pada saat berinteraksi. Masingmasing harus memilih kata sapaan yang tepat berdasarkan tata krama dan norma adat istiadat. Sapaan menurut kedudukan ini membedakan usia dan strata sosial, sehingga sapaan yang digunakan akan tampak bervariasi. Misalnya: antara menantu dan mertua, antara kakak dan adik, meskipun dalam kedudukan dan status sama tetapi strata sosialnya berbeda.

\section{1) Sapaan Bapa/Nanang dan Mé/Mémé}

Sapaan Pa/Bapa atau Nang/Nanang ditujukan kepada seorang tua laki-laki (ayah) atau ayah mertua dari keluarga orang kebanyakan (wangsa jaba) yang disapa oleh anaknya atau oleh menantunya. Contohnya:

(4) Nyén ngejang baju daki dini, Pa?

(5) Dija ngalih nyuh nguda lakar saté, Nang?

Demikian seorang anak atau menantu misalnya yang bernama Luh Rai menyapa ayahnya atau mertua laki-lakinya. Kalimat tersebut berarti,

(4) 'Siapa menaruh baju kotor di sini, Pak?

(5) 'Di mana mencari kelapa muda untuk saté, Yah?

Demikian jika yang disapa seorang tua laki-laki. Jika yang disapa seorang perempuan merupakan ibu atau mertua perempuan dari keluarga orang kebanyakan (wangsa jaba), sapaannya mé atau mémé seperti contoh berikut.

(4a) Nyén ngejang baju daki dini, Mé?

(5a) Dija ngalih nyuh nguda lakar saté, Mé?

Demikian seorang anak atau menantu misalnya yang bernama Putu Darma menyapa ibunya atau mertua perempuannya. Kalimat tersebut berarti,

(4a) 'Siapa menaruh baju kotor di sini, Bu?

(5a) 'Di mana mencari kelapa muda untuk saté, Bu?

\section{2) Sapaan Aji/Ajung dan Biang/Ibu}

Sapaan Aji/Ajung dikenakan bagi seorang tua laki-laki (ayah) atau ayah mertua dari keluarga orang keturunan triwangsa (brahmana, ksatria, wesia) yang disapa oleh anaknya atau oleh menantunya. Contohnya:

(6) Bin pidan payu luas ka Lombok, Jik?

(7) Dija ada anak ngadep nasi séla, Jung?

Demikian seorang anak atau menantu keluarga bangsawan misalnya yang bernama Cokorda Isteri Laksmi menyapa ayahnya atau mertua laki-lakinya. Kalimat tersebut berarti,

(6) 'Kapan jadi berangkat ke Lombok, Ayah?'

(7) 'Di mana ada orang menjual nasi ketela, Ayah?'

Sapaan jik singkatan dari kata ajik 'ayah' sangat umum dikenakan terhadap ayah keturunan brahmana (ida bagus) maupun ksatria (anak agung, cokorda, gusti), sedangkan sapaan jung singkatan dari kata ajung 'ayah' hanya digunakan oleh keturunan ksatria (anak agung dan cokorda) tertentu saja, maksudnya kebiasaan keluarga tertentu saja.

Demikian jika yang disapa seorang ayah atau mertua tua laki-laki. Jika yang disapa seorang perempuan merupakan ibu atau mertua perempuan dari keluarga orang bangsawan (triwangsa), sapaannya biang atau ibu, seperti contoh berikut.

(6a) Bin pidan payu luas ka Lombok, Biang?

(7a) Dija ada anak ngadep nasi séla, Ibu?

Demikian seorang anak atau menantu keluarga bangsawan misalnya yang bernama Ida Bagus Made Sika menyapa ibunya atau mertua perempuannya. Kalimat tersebut berarti,

(6a) 'Kapan jadi berangkat ke Lombok, Ibu?'

(7a) 'Di mana ada orang menjual nasi ketela, Ibu?'

Bagi masyarakat triwangsa, sapaan biang 'ibu' hanya digunakan oleh keluarga tertentu saja terutama keturunan dewa, brahmana, dan gusti (tergantung kebiasaan). Sementara itu, sapaan $i b u$ 'ibu' lebih umum digunakan oleh keluarga anak agung dan cokorda.

\section{3) Sapaan Ning/Cening dan Gus/Gung}

Seorang anak laki-laki dari keturunan orang kebanyakan (Wangsa Jaba) disapa oleh ayah, ibu, atau 
mertuanya dengan menyebut namanya atau sapaan Ning/ Cening seperti pada contoh berikut.

(8) Aduh ... eda menék tegeh-tegeh, Ning!

(9) Jani Cening suba kelih adané, patut jemet malajah!

Demikian bahasa seorang tua misalnya Pan Kaler atau Men Lecir menyapa seorang anak laki-laki keturunan orang kebanyakan (wangsa jaba) misalnya I Ketut Darma, jadi mereka tidak menyebut nama I Ketut Darma atau Darma, melainkan Ning atau Cening. Kalimat tersebut berarti

(8) 'Aduh ... jangan naik tinggi-tinggi, Nak!'

(9) 'Sekarang Nanak sudah makin dewasa, harus rajin belajar!'

Kalimat di atas untuk anak-anak keturunan orang kebanyakan (wangsa jaba). Jika yang disapa anak lakilaki dari keturunan orang bangsawan (triwangsa) akan menggunakan sapaan Gus/Gung seperti pada kalimat seperti contoh di bawah ini.

(8a) Aduh ... eda menék tegeh-tegeh, Gus!

(9a) Jani Gung ampun duur adané, patut jemet malajah!

Demikian bahasa seorang dewasa atau tua ketika menyapa seorang anak laki-laki keturunan bangsawan (triwangsa) misalnya Ida Bagus Rai atau Anak Agung Mahendra, jadi mereka tidak menyebut nama Gus Rai atau Gung Mahendra, melainkan Gus atau Gung. Kalimat tersebut berarti

(8a) 'Aduh ... jangan naik tinggi-tinggi, Gus?'

(9a) 'Sekarang Nanak sudah makin dewasa, harus rajin belajar!'

Sapaan dengan kata gus 'nak' digunakan untuk menyapa anak laki-laki keturunan kasta brahmana, sedangkan kata gung 'nak' digunakan untuk menyapa anak laki-laki keturunan anak agung, gustu agung, dan dewa agung.

\section{4) Sapaan Luh dan Gék/Yuk}

Sapaan Luh dan Gék/Yuk dikenakan terhadap seorang anak perempuan yang disapa oleh ayah, ibu, atau mertuanya. Sapaan Luh untuk anak perempuan dari keluarga orang kebanyakan (Wangsa Jaba), sedangkan sapaan Gek/Yuk bagi keturunan keluarga bangsawan (Triwangsa). Perhatikan contoh berikut.

(10) Tulung jemakang jep bapa payung, Luh!

(11) Tulung jemakang jep ajik payung Gék/Yuk!

Demikian seorang ayah misalnya bernama Pak Gunawan atau orang tua triwangsa Gung Aji Satria kepada seorang anak perempuan misalnya Luh Manik (wangsa jaba) dan atau Ida Ayu Laksmi (triwangsa), yang terjemahannya sebagai berikut.
(10) 'Tolong ambilkan ayah payung, Luh!'

(11) 'Tolong ambilkan ayah payung, Gek/Yuk!'

\section{5) Sapaan Buk, Méméné atau Menyebut Nama}

Seorang suami akan menyapa isterinya dengan kata buk atau menyebut nama isteri atau nama singkatnya. Misalnya isterinya bernama Luh Manik, maka sapaannya seperti pada contoh kalimat berikut.

(12) Suba suud nyakan, Buk?

(12a) Suba suud nyakan, Méméné?

(12b) Suba suud nyakan, Nik?

Kalimat-kalimat di atas digunakan oleh seorang suami keturunan orang kebanyakan (wangsa jaba) yang misalnya bernama Bapak Gede Hartawan untuk menyapa isterinya yang bernama Ni Made Wardani, tidak menyebut nama asli isterinya. Terjemahan kalimat tersebut sebagai berikut.

(12) 'Sudah selesai memasak, Bu?'

(12a) 'Sudah selesai memasak, Bu?'

(12b) 'Sudah selesai memasak, Manik?'

Jika seorang suami wangsa jaba membicarakan isterinya kepada orang ketiga akan digunakan kata milik kurenan tiangé 'isteri saya' atau menyebut nama anak sulungnya, seperti pada contoh kalimat berikut.

(13) Luh Rai suba luas ajaka kurenan tiangé.

(13a) Luh Rai suba luas ajaka ibukné Budi.

Misalnya sang isteri bernama Luh Manik, anak sulungnya bernama Budiasa, sang suami menyebut isterinya dengan bentuk sapaan kurenan tiange 'isteri saya' dan atau ibukne Budi 'ibunya Si Budi'. Jadi, si pembicara tidak akan menyebut nama isterinya. Terjemahan selengkpnya kalimat di atas sebagai berikut. (13) 'Luh Rai sudah pergi bersama isteri saya' (13a) 'Luh Rai sudah pergi bersama ibunya Budiasa'

\section{6) Sapaan Pak atau Bapané}

Seorang isteri akan menyapa suaminya dengan kata Pak atau bapané. Berbeda dengan sapaan suami terhadap isteri yang dapat menyebut nama isteri. Pada sapaan seorang isteri tidak umum menyebut nama suami. Hal ini sudah menjadi tradisi bahwa dianggap tabu atau kurang hormat jika seorang isteri menyebut nama suaminya. Perhatikan contoh berikut!

(14) Bapak sing nyidang libur buin puan, Pak?

(14a) Nyén maan giliran ngayah banjar jani, Bapané?

Demikian seorang isteri keturunan wangsa jaba misalnya bernama Luh Kartika Sari, ketika bertanya kepada suaminya yang bernama I Made Lara, tidak akan menyebut nama suami, melainkan dengan sapaan seperti di atas, yang terjemahnnya sebagai berikut.

(14) 'Ayah tidak bisa libur lagi du hari, Yah?'

(14a) 'Siapa mendapat giliran ngayah sekarang, Pak?' 
Selanjutnya, jika seorang isteri membicarakan suaminya kepada pihak lain, sangat umum menggunakan kata milik kurenan tiangé 'suami saya' atau menyebut nama anak sulungnya. Misalnya sang isteri bernama Suparta, anak sulungnya bernama Arik, sang isteri menyebut suaminya dengan bentuk sapaan di bawah ini.

(15) Pak Madé suba luas ajaka kurenan tiangé.

'Pak Made sudah pergi bersama suami saya'

(15a) Pak Made suba luas ajaka bapakné Arik.

'Pak Made sudah pergi bersama bapaknya Arik'

\section{7) Sapaan Kak/Pekak dan Dong/Dadong}

Seorang cucu akan menyapa kakeknya dengan kata $k a k$ atau pekak. Berbeda dengan sapaan suami terhadap isteri yang dapat menyebut nama isteri. Pada sapaan seorang isteri tidak umum menyebut nama suami. Contoh kalimat berikut.

(16) Kak sing bisa masatua Bali, Kak?

(16a) Dong, pidan Dadong taén masekolah?

Demikian sapaan Nyoman Mandia, seorang cucu keturunan wangsa jaba menyapa kakeknya yang bernama Pekak Budi, menggunakan sapaan Kak 'Kakek', tidak menyebut nama kakeknya. Terjemahan kalimat di atas sebagai berikut.

(16) 'Kakek tidak bisa mendongeng Bali, Kek?'

(16a) 'Nek, dulu Nenek petnah bersekolah?'

\section{Sapaan Menurut Jenis Kelamin}

Perbedaanjenis kelaminmengakibatkan munculnya istilah-istilah seperti pria, wanita, ayah, ibu, nenek, kakek, suami, istri, paman, bibi, dan sebagainya dalam bahasa Indonesia. Bahasa Bali juga memiliki sejumlah kata atau istilah yang menunjukkan jenis kelamin laki-laki dan perempuan.

\section{1) Sapaan untuk Laki-laki}

Ada sejumlah kata sapaan bahasa Bali yang biasa digunakan dalam bertutur sapa, khususnya yang terkait dengan jenis kelamin laki-laki sebagai berikut.

(a) Sapaan laki-laki bangsawan (triwangsa):

gus, gung, cok 'nak' (untuk anak-anak)

jik, aji, jung 'ayah' (untuk bapak/ayah)

jung wa/uwa 'paman' (untuk paman)

kakiang, gung kak 'kakek' (untuk kakek-kakek)

(b) Sapaan laki-laki orang kebanyakan (wangsa jaba): ning, gus 'nak' (untuk anak-anak)

pa, nang, pak 'ayah' (untuk bapak/ayah) wa/uwa 'paman' (untuk paman) kak, kaki 'kakek' (untuk kakek-kakek)

(b)Sapaan laki-laki bangsawan (triwangsa): gus/gung 'nak' (untuk anak-anak) jik, aji, jung 'ayah' (untuk bapak/ayah) jung wa/uwa 'paman' (untuk paman) kakiang, gung kak 'kakek' (untuk kakek-kakek) (b) Sapaan laki-laki orang kebanyakan (wangsa jaba): ning, gus 'nak' (untuk anak-anak) pa, nang, pak 'ayah' (untuk bapak/ayah) wa/uwa 'paman' (untuk paman) kak, kaki 'kakek' (untuk kakek-kakek)

\section{2) Sapaan untuk Perempuan}

Di samping kata sapaan untuk laki-laki, ada juga sejumlah kata sapaan untuk perempuan yang biasa digunakan dalam bertutur sapa bahasa Bali sebagai berikut.

(a) Sapaan perempuan bangsawan (triwangsa): gék, yuk 'mbak yu' (untuk anak-anak) biang, bu, ibu 'ibu/bu' (untuk ibu-ibu) ni, niang 'nenek' (untuk nenek-nenek) pi/kumpi 'kumpi' (untuk kumpi)

(b) Sapaan perempuan orang kebanyakan (wangsa jaba): gék, luh, yuk 'mbak yu' (untuk anak-anak) buk, mek, mak'ibu/bu' (untuk ibu-ibu) dadong, odah 'nenek' (untuk nenek-nenek) pi/kumpi 'kumpi' (untuk kumpi)

Berikut disajikan daftar bentuk sapaan yang disertai dengan peran, usia, dan fungsi penyapa dan pesapa.

Tabel 1. Daftar Kata Sapaan Berdasarkan Peran, Usia, dan Fungsinya

\begin{tabular}{|c|c|c|c|c|}
\hline No. & Sapaan & Peran & Usia Penyapa & $\begin{array}{l}\text { Fungsi } \\
\text { Pesapa } \\
\end{array}$ \\
\hline 1 & bapa/bapak & pesapa & lebih muda & $\begin{array}{l}\text { ayah dari } \\
\text { penyapa atau } \\
\text { orang lain } \\
\text { (kebanyakan) }\end{array}$ \\
\hline 2 & aji/ajung & pesapa & lebih muda & $\begin{array}{l}\text { ayah dari } \\
\text { penyapa atau } \\
\text { orang lain } \\
\text { (bangsawan) }\end{array}$ \\
\hline 3 & $\begin{array}{l}\text { mémé/ibu/ } \\
\text { mamak }\end{array}$ & pesapa & lebih muda & $\begin{array}{l}\text { ibu dari } \\
\text { penyapa atau } \\
\text { orang lain }\end{array}$ \\
\hline 4 & bu/ibu, biang & pesapa & lebih muda & $\begin{array}{l}\text { ibu dari } \\
\text { penyapa atau } \\
\text { orang lain } \\
\text { (bangsawan) }\end{array}$ \\
\hline 5 & bli/beli & pesapa & lebih muda & $\begin{array}{l}\text { kakak laki } \\
\text { penyapa atau } \\
\text { orang lain } \\
\text { (kebanyakan) }\end{array}$ \\
\hline 6 & $w i$ & pesapa & lebih muda & $\begin{array}{l}\text { kakak laki } \\
\text { penyapa atau } \\
\text { orang lain } \\
\text { (bangsawan) }\end{array}$ \\
\hline 7 & embok & pesapa & lebih muda & $\begin{array}{l}\text { kakak wanita } \\
\text { penyapa } \\
\text { atau orang lain }\end{array}$ \\
\hline 8 & $\begin{array}{l}\text { yan, dé, man, } \\
\text { tut, tu, mang, } \\
\text { dék, }\end{array}$ & pesapa & lebih tua & $\begin{array}{l}\text { adik penyapa } \\
\text { orang } \\
\text { kebanyakan }\end{array}$ \\
\hline 9 & gus/gék & pesapa & lebih tua & $\begin{array}{l}\text { adik penyapa } \\
\text { orang } \\
\text { bangsawan }\end{array}$ \\
\hline 10 & wa/uwa & pesapa & lebih muda & $\begin{array}{l}\text { paman dari } \\
\text { penyapa } \\
\text { (orang } \\
\text { kebanyakan) }\end{array}$ \\
\hline
\end{tabular}




\begin{tabular}{|c|c|c|c|c|}
\hline 11 & $\begin{array}{l}\text { jung wal } \\
\text { ajung wa }\end{array}$ & pesapa & lebih muda & $\begin{array}{l}\text { paman dari } \\
\text { penyapa } \\
\text { (orang } \\
\text { bangsawan) }\end{array}$ \\
\hline 12 & bik/bibik & pesapa & lebih muda & $\begin{array}{l}\text { bibik dari } \\
\text { penyapa }\end{array}$ \\
\hline 13 & $\begin{array}{l}\text { kak/pekak/ } \\
\text { kiang } \\
\text { kaki }\end{array}$ & pesapa & lebih muda & $\begin{array}{l}\text { kakek dari } \\
\text { penyapa } \\
\text { (orang } \\
\text { kebanyakan) }\end{array}$ \\
\hline 14 & $\begin{array}{l}\text { kakiang/gung } \\
\text { kak }\end{array}$ & pesapa & lebih muda & $\begin{array}{l}\text { kakek dari } \\
\text { penyapa } \\
\text { (orang } \\
\text { bangsawan) }\end{array}$ \\
\hline 15 & $\begin{array}{l}\text { dong/ } \\
\text { dadong/odah } \\
\text { mbah,nini }\end{array}$ & pesapa & lebih muda & $\begin{array}{l}\text { nenek dari } \\
\text { penyapa } \\
\text { (orang } \\
\text { kebanyakan) }\end{array}$ \\
\hline 16 & $\begin{array}{l}\text { nini/niang/ } \\
\text { gung } \\
\text { nini }\end{array}$ & pesapa & lebih muda & $\begin{array}{l}\text { nenek dari } \\
\text { penyapa } \\
\text { (orang } \\
\text { bangsawan) }\end{array}$ \\
\hline 17 & $\begin{array}{l}\text { pak yan, pak } \\
\text { de, pak man, } \\
\text { pak tut, } \\
\text { pak tu, pak } \\
\text { dek }\end{array}$ & pesapa & lebih muda & $\begin{array}{l}\text { bapak-bapak } \\
\text { dari orang } \\
\text { kebanyakan } \\
\text { disapa oleh } \\
\text { yang lebih } \\
\text { muda }\end{array}$ \\
\hline 18 & $\begin{array}{l}\text { buk yan, buk } \\
\text { de, buk man, } \\
\text { buk tut, } \\
\text { buk tu, buk } \\
\text { dek, }\end{array}$ & pesapa & lebih muda & $\begin{array}{l}\text { ibuk-ibuk } \\
\text { dari orang } \\
\text { kebanyakan } \\
\text { disapa oleh } \\
\text { yang lebih } \\
\text { muda }\end{array}$ \\
\hline
\end{tabular}

\section{Sapaan Menurut Hubungan Keluarga Langsung}

Hubungan keluarga langsung masih dibedakan menjadi hubungan langsung vertikal (urutan orang-orang yang melahirkan), dan hubungan langsung horizontal/ hubungan sejajar (hubungan antarorang yang masih mempunyai hubungan satu ayah, satu ibu, satu nenek.

\section{1) Hubungan Keluarga Langsung Vertikal}

Bentuk-bentuk sapaan bagi orang-orang yang terikat dalam hubungan langsung vertikal adalah sebagai berikut.

\section{(a) Sapaan Pekak dan Dadong}

Pekak dan dadong adalah bentuk sapaan untuk orang tua laki dan perempuan dari ayah/ibu. Dapat berarti kakek dan nenek. Sapaan pekak sering disingkat kak dan dadong disingkat dong. Dalam percakapan langsung sebutan pekak dan dadong dapat berdiri sendiri tanpa tambahan kata apa pun di belakangnya. Perhatikan contoh data berikut ini.

(17) Pekak suba ngajeng?

'Kakek sudah makan?'

(17a) Suba ngajng busan, Kak?

'Sudah makan tadi, Kek?'

(18) Dija dadong lakar sirep?

"Di mana nenek akan tidur?'

(18a) Dija lakar sirep, Dong?

"Di mana akan tidur, Nek?'

Kalimat (17 dan 18) menunjukkan komunikasi dengan orang yang usianya jauh lebih tua sangat memperhatikan nilai-nilai kesopanan bertutur sapa, sesuai tradisi masyarakat Bali. Kata-kata seperti ngajeng 'makan' pada kalimat (17), juga kata sirep 'tidur' pada kalimat (18) memiliki nilai rasa yang lebih halus dari kata yang biasa dipakai dengan orang sebaya yaitu ngalih nasi atau madaar untuk kata ngajeng 'makan' dan kata pules untuk kata sirep 'tidur'.

\section{(b) Sapaan Bapa dan Mémé}

Bapa dan méméberarti 'ayah' dan 'ibu'. Selain bapa, bapak 'ayah' digunakan juga bentuk sapaan lain, yaitu mémé, ibuk, dan mamak 'ibu'. Dalam percakapan sehari-hari sapaan bapa sering disingkat pa atau pak, dan kata mémé disingkat mé atau buk atau mak. Perhatikan contoh di bawah ini.

(19) Bapa lakar kija?

'Ayah mau kemana?'

(20) Meme suba manjus?

'Ibu sudah mandi?'

Sapaan bapa 'ayah' dan meme 'ibu' di atas digunakan bagi mayarakat Bali dari strata sosial yang paling umum. Kata sapaan bapa 'ayah' dan meme 'ibu' untuk triwangsa atau kaum bangsawan adalah aji/ajung 'ayah' dan ibu/biang 'ibu'.Perhatikan contoh kalimat berikut!
(21) Aji/ajung jagi ngajeng mangkin?
'Ayah mau makan sekarang?'
(22) Dija ibu/biang numbas wastra ndek punika?
'Di mana ibu membeli kain ndek itu?'

\section{(c) Sapaan Ning dan Luh}

Sapaan ning singkatan dari cening 'nak' digunakan untuk menyapa anak laki-laki di kalangan masyarakat umum. Sapaan luh singkatan dari iluh dipakai untuk menyapa anak-anak perempuan dari kalangan orang kebanyakan. Sebagai contoh:

(23) To ngudiang jag neyebeng uli tuni, Ning?

'Mengapa selalu cemberut dari tadi, Nak?'

(24) Memeh jegegne, kal kija to Luh?

'Aduh, cantik sekali, akan ke mana itu Nak?'

Sapaan anak laki-laki untuk golongan triwangsa atau bangsawan menggunakan kata gus/gung/cok 'nak' dan untuk anak perempuan dari triwangsa menggunakan kata gek/gung ayu/cok 'nak' seperti pada contoh berikut.

(25) Gung Gus jagi lunga kija mangkin?

'Gung Gus mau ke mana sekarang?'

(26) Ring dija mangkin ngranjing Cok?

'Di mana sekarang sekolah Cok?'

(27) Yu gek sampun marayunan wawu?

'Yu gek sudah makan tadi?'

(29) Malih pidan jagi durus malancaran, Cok?

'Kapan akan jadi melancong, Cok?'

\section{2) Hubungan Keluarga Langsung Horizontal}

Bentuk-bentuk sapaan yang digunakan untuk menyapa orang-orang yang terikat dalam hubungan langsung horizontal sebagai berikut. 


\section{(a) Sapaan Beli}

Kata sapaan beli berarti 'kakak laki-laki'. Dalam percakapan sehari-hari sering disingkat Bli. Kata sapaan beli bersifat terbatas (artinya hanya dapat digunakan untuk menyapa kakak laki-laki), serta dapat digunakan dalam sapaan langsung dan tak langsung. Perhatikan contoh berikut.

(30) Bli, dija ada anak ngadep don lontar?

'Kak, di mana ada orang menjual daun lontar?'

(31) Dija kurenan bline magae, Bli?

'Dimana istrimu bekerja, Kak?'

(32) Suba ulihang Bli bukune Luh Rai?

'Sudah Kakak kembalikan bukunya Luh Rai?'

\section{(b) Sapaan Mbok}

Kata sapaan mbok berarti 'kakak perempuan'. Kata sapaan mbok juga bersifat terbatas (artinya hanya dapat digunakan untuk menyapa kakak perempuan), serta dapat digunakan dalam sapaan langsung dan tak langsung. Perhatikan contoh berikut.

(33) Mbok, dija mbok kuliah jani?

'Kak, di mana kakak kuliah sekarang?'

(34) Saja kurenan mboke suba pensiun, Mbok?

'Benar suaminya kakak sudah pensiun, Kak?'

\section{(c) Sapaan Urutan Kelahiran}

Kata sapaan urutan kelahiran meliputi: yan/wayan, de/made/gede, man/nyoman, tut/ketut, tu/putu, dek/kadek, dan mang/komang. Semua kata sapaan tersebut bersifat netral (dapat digunakan untuk menyapa laki-laki dan atau perempuan) dan dapat digunakan dalam sapaan langsung dan tak langsung. Perhatikan contoh berikut.

(35) Lakar kija jani, Yan?

'Akan ke mana sekarang, Yan'

(36) Ngudiang entungang jukute, De?

'Mengapa dibuang sayurnya, De?'

(37) Man, payu cai/nyai ngabaang mboke nasi?

'Man, jadi kamu membawakan kakakmu nasi?'

\section{(d) Sapaan Uwa}

Sapaan $u w a$ berarti 'paman'. Kata $u w a$ digunakan untuk menyapa saudara laki dari ayah atau ibu. Dapat digunakan dalam sapaan langsung dan tak langsung. Perhatikan contoh data berikut ini.

(38) Uwa, pidan uwa teka uli Jakarta?

'Paman, kapan paman datang dari Jakarta?'

(39) Buin pidan odalan di pura desa, Uwa?

'Kapan odalan di pura desa, Paman?'

(40) Uwa,pidan meli kedis titiran ane ba duur to?

'Paman, kapan membeli perkutut yang di atas itu?'

\section{(e) Sapaan Bibik}

Kata sapaan bibik berarti 'bibi'. Kata sapaan bibik yang sering disingkat bik digunakan untuk menyapa adik perempuan dari ayau dan atau ibu. Dapat digunakan dalam sapaan langsung dan tak langsung. Perhatikan contoh berikut ini.

(41) Dija meli kain ndek ane asli, Bik?

'Di mana membeli kain ndek yang asli, Bik?'

(42) Bibik, jani lakar malali kuman tiang?

'Bibik, sekarang mau main ke rumah saya?'

\section{SIMPULAN}

Kata sapaan dalam bahasa Bali cukup banyak dan bervariasi. Hal itu disebabkan oleh bentuk hubungan kekerabatan yang meliputi faktor: (1) usia partisifan, (2) kedudukan dalam keluarga, (3) jenis kelamin, dan (4) hubungan keluarga langsung. Penggunaan bentuk-bentuk sapaan dalam bahasa Bali dapat mengalami perubahan bentuk atau varian tergantung situasi pembicaraan dan dan status sosial para partisipan. Artinya, sapaan dalam bentuk bahasa biasa digunakan pada keluarga wangsa jaba atau orang kebanyakan dan yang termasuk kata-kata bahasa Bali halus digunakan pada keluarga triwangsa atau bangsawan karena bahasa Bali mengenal sistem anggah-ungguh kruna atau tingkat-tingkatan kata.

\section{DAFTAR PUSTAKA}

Djajasudarma, T.F. (2003). Analisis Bahasa Sintaksis dan Semantik. Bandung: Uvula Press Fakultas Sastra Universitas Padjadjaran.

Firdaus, W. (2011). Kata-Kata Serapan Bahasa Aceh dari Bahasa Arab: Analisis Morfofonemis. Sosiohumaniora, Vol. 13 (2): 223-234.

Fishman, J.A. (1986). Directions in Sociolinguistics: Etnography of Communi-cations. New Holt: Renehard and Winston

Koentjaraningrat. (1990). Beberapa Pokok Antropologi Sosial. Jakarta: Dian Rakyat.

Kridalaksana, H. (1982). Kamus lingustik. Edisi Pertama. Jakarta: PT Gramedia Pustaka Utama

Ramlan, M. (1987). Sintaksis. Yogyakarta: C.V. Karyono.

Sofyan, A.N. (2015). Frasa Direktif yang Berunsur Di, Dari, Dan Untuk Dalam Bahasa Indonesia: Kajian Sintaktis dan Semantis. Sosiohumaniora. Vol. 17 (3): 262-266

Sudaryanto. (1982). Metode Linguistik: Kedudukan, Aneka Isinya, dan Faktor Penentu Wujudnya. Yogyakarta: Fak. Sastra dan Kebudayaan, Universitas Gajah Mada. 